\title{
Luminescence anion sensing via modulation of MLCT emission from a naphthalimide-Ru(II)-polypyridyl complex
}

\author{
Robert B. P. Elmes and Thorfinnur Gunnlaugsson* \\ School of Chemistry, Centre for Synthesis and Chemical Biology, Trinity College Dublin, Dublin 2, Ireland.
}

\begin{abstract}
The selective sensing of fluoride $\left(\mathrm{F}^{-}\right.$; an important breakdown product of some chemical warfare agents such as sarin) was achieved by observing quenching in the Metal to Ligand Charge Transfer (MLCT) emission of the 1,8-naphthalimide ruthenium conjugate Ru-Nap- $\mathbf{N H}_{2}$, which occurs at long wavelengths in $\mathrm{CH}_{3} \mathrm{CN}$, using steady state fluorescence spectroscopy. The $\mathrm{F}^{-}$recognition was also visible to the naked eye, with a clear colour change from yellow to red. The sensing mechanism is most likely initially via hydrogen bonding, between the anion and the amine, which at higher concentrations, gives rise to deprotonation of the acidic 4-amino-1,8naphthalimide moiety. However, counter ion effects may also be contributing to the overall emission changes. Other anions such as acetate, phosphate and chloride also give rise to quenching in the fluorescence emission with only minor changes in the UV-Vis absorption spectra of Ru-Nap- $\mathbf{N H}_{2}$. Moreover, phosphate also gave rise to shifts in the $\lambda_{\max }$ in the emission spectra. (c) 2010 Elsevier Science. All rights reserved
\end{abstract}

The recognition and sensing of anions has become an important area of supramolecular chemistry. ${ }^{1-3}$ Many anions play an important role in both physiology and in the environment, and several examples of both colorimetric and fluorescence sensors have been developed. ${ }^{4-6}$ To date, most anion sensors have been based on the use of both hydrogen bonding based receptors, ${ }^{7,8}$ and positively charged systems, such as (poly)ammonium, ${ }^{9}$ guanadinium ${ }^{10}$ or Lewis Acids, ${ }^{11}$ where the anion binding/recognition can occur either through hydrogen bonding or electrostatic interactions. ${ }^{12}$ While the sensing of biologically relevant anions should ideally be achieved using water soluble agents/sensors, ${ }^{13}$ it is most commonly carried out in organic media. ${ }^{14}$ In solvents such as DMSO, $\mathrm{CHCl}_{3}$ and $\mathrm{CH}_{3} \mathrm{CN}$, other recognition processes can also take place, such as deprotonation, a phenomenon investigated in detail by Gale, ${ }^{15}$ Tian, ${ }^{16}$ and Fabbrizzi, ${ }^{17}$ as well as our own research group. $^{18}$ Using the 4-amino-1,8-naphthalimide structure, which possesses long wavelength absorption $\left(\lambda_{\max }\right.$ Abs $\approx$ $440 \mathrm{~nm})$, and emission spectra $\left(\lambda_{\max } \mathrm{Em} \approx 520 \mathrm{~nm}\right)$, due to the presence of an internal charge transfer (ICT), we have shown that basic anions such as fluoride $\left(\mathrm{F}^{-}\right)$can cause deprotonation of the 4-amino moiety giving rise to a quenching of the naphthalimide emission. ${ }^{18}$ We have also used the 4-amino-1,8-naphthalimide chromophore for the sensing of cations and in the imaging of bone structues, ${ }^{19}$ and in the development of novel DNA binding agents. ${ }^{20}$ An example of the latter, is the $\mathrm{Ru}(\mathrm{II})$-polypyridyl complex Ru-Nap- $\mathbf{N H}_{2}$ shown in Scheme 1, which binds strongly to

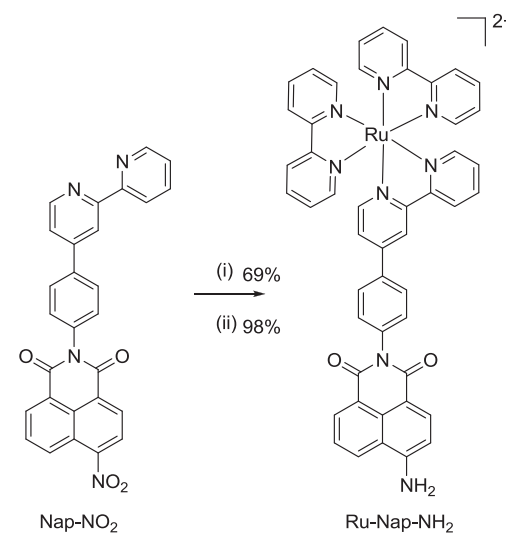

Scheme 1. Synthesis of the $\mathrm{Ru}(\mathrm{II})$ based sensor $\mathbf{R u}-\mathbf{N a p}-\mathbf{N H}_{2}$ from the precursor Nap- $\mathrm{NH}_{2}$. (i) $\mathrm{Ru}(\mathrm{bpy})_{2} \mathrm{Cl}_{2}, \mathrm{DMF} / \mathrm{H}_{2} \mathrm{O}, \mathrm{Ar}, \Delta$; (ii) $\mathrm{Pd} / \mathrm{C}, \mathrm{MeOH}$.

DNA in competitive media, with concomitant changes in both the ground and the excited state properties of both the naphthalimide and the $\mathrm{Ru}(\mathrm{II})$ metal to ligand charge transfer (MLCT) transitions. ${ }^{20 \mathrm{~b}}$ Herein, we show that this structure can also function as an anion sensor, showing a strong bias for fluoride $\left(\mathrm{F}^{-}\right)^{21}$ over other anions such as acetate $\left(\mathrm{AcO}^{-}\right)$and other halides, in $\mathrm{CH}_{3} \mathrm{CN}$ solution. The advantage of this system over that previously developed by us $^{18}$ is that the anion recognition at the naphthalimide site interferes with the energy transfer mechanism from the naphthalimide moiety to the Ru(II) MLCT excited state, causing the long wavelength red Ru-centred emission to be effectively fully quenched.

\footnotetext{
Corresponding author. Tel.: + 3531896 3459; fax: + 3531671 2826; e-mail: gunnlaut@tcd.ie.
} 


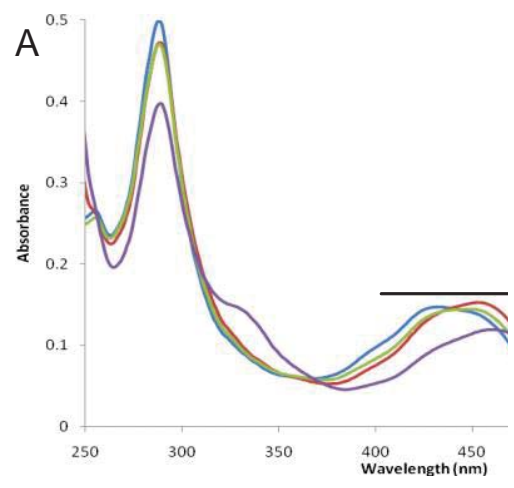

previously seen for such 1,8-naphthalimide based sensors that possess acidic protons, e.g. the 4-amino moiety, that can be deprotonated. ${ }^{18}$ In contrast to these results, significant changes were observed in the emission spectrum of Ru-Nap- $\mathbf{N H}_{2}$ in the presence of various anions, Figure 1B. Excitation at $432 \mathrm{~nm}$, (which should address both the naphthalimide and the MLCT absorption bands), gave rise to the formation of a long emitting and broad emission band entered at $615 \mathrm{~nm}$, assigned to the MLCT emission alone, and a shoulder at $c a$. $505 \mathrm{~nm}$ which we assigned to the naphthalimide emission. As excitation at $432 \mathrm{~nm}$ addresses both excited states, the lack of any naphthalimide emission suggests that an efficient energy transfer mechanism exists from the naphthalimide singlet excited state (Nap $S^{1}$ ) to the MLCT*. Upon addition of the aforementioned anions, considerable changes were seen in

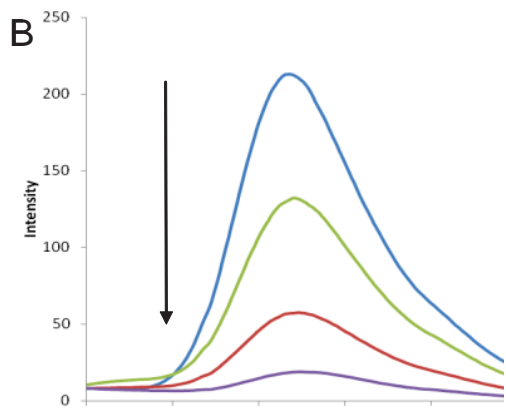

Figure 1. A) The changes in the absorption spectra of $\mathbf{R u}-\mathbf{N a p}-\mathbf{N H}_{2}$ in $\mathrm{CH}_{3} \mathrm{CN}$ in the absence (-), and the presence of $\mathrm{AcO}^{-}, \mathrm{Cl}^{-}$and $\mathrm{F}^{-}$as their TBA salts. B) The corresponding changes in the emission spectra upon excitation at $432 \mathrm{~nm}$.

The use of transition metal ion based polypyridyl complexes in anion sensing has been demonstrated by Beer et al. $^{22}$ as well as by Sessler and co workers, ${ }^{23}$ who have used phen-Co(II) complexes and hydrogen bonding dipyrrolylquinoxaline systems, while Tian et al. ${ }^{16 a}$ have employed zinc porphyrin naphthalimide triads. More recently Baitalik et $\mathrm{al}^{24}$ used $\mathrm{Ru}(\mathrm{II})$ complexes of 4,5bis(benzimidazol-2-yl)imidazole ligands in anion sensing, while Sojic and Pinet, ${ }^{25}$ developed a guanidinium 3,3'functionalised bipyridyl Ru(II) complex for anion sensing. The synthesis of the Ru-Nap- $\mathbf{N H}_{\mathbf{2}}$ complex was previously reported by us, ${ }^{19}$ involving the formation of $\mathbf{R u}-\mathbf{N a p}-\mathbf{N O}_{2}$ from $\mathbf{N a p}-\mathbf{N O}_{2}$ in a two-step synthesis, as summarised in Scheme 1.

In $\mathrm{CH}_{3} \mathrm{CN}$ solution, Figure $1 \mathrm{~A}$, the absorption spectrum of Ru-Nap- $\mathbf{N H}_{2}$ gave rise to a broad band centred at $432 \mathrm{~nm}$, assigned to the naphthalimide unit and the MLCT transitions $\left(\varepsilon=11,694 \mathrm{~cm}^{-1} \mathrm{M}^{-1}\right)$, and a narrower band at shorter wavelengths assigned to intraligand and naphthalimide $\pi-\pi$ transitions $\left(\varepsilon=39,365 \mathrm{~cm}^{-1} \mathrm{M}^{-1}\right)$. Upon addition of an excess of various anions, little or no changes were observed in the absorption spectrum, the most significant being seen upon addition of $\mathrm{F}^{-}$(as tetra- $n$ butylammonium (TBA) salt), where the long wavelength band was red shifted, and the appearance of a shoulder, centred at $c a$. $340 \mathrm{~nm}$, was observed, which was assigned to the naphthalimide $\pi-\pi$ transition (Figure 1A). The transitions were also clearly visible in the excitation spectrum. These changes are somewhat smaller than the MLCT emission, Figure 1B, being most pronounced for $\mathrm{F}^{-}$, where the emission was quenched by $c a .91 \%$, while $\mathrm{AcO}^{-}$and $\mathrm{Cl}^{-}$gave rise to $73 \%$ and $39 \%$ emission
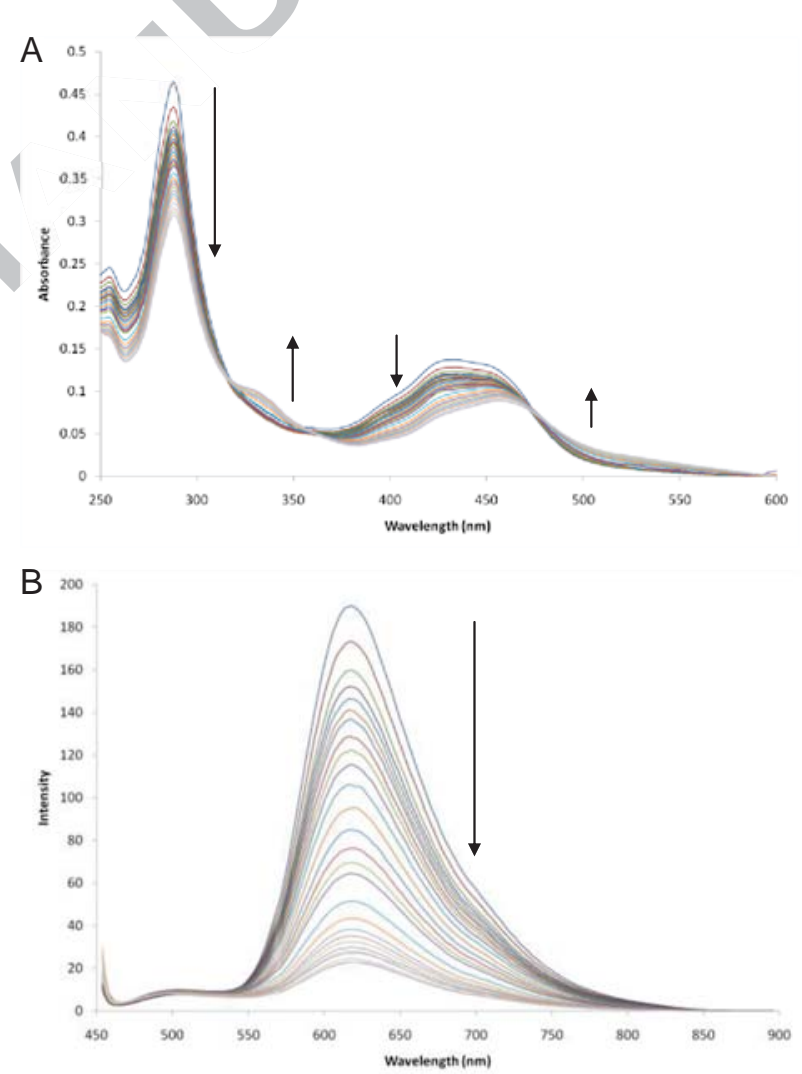

Figure 2. A) The changes in the absorption spectrum of Ru-Nap- $\mathbf{N H}_{2}$ in $\mathrm{CH}_{3} \mathrm{CN}$ upon titration with TBAF $\left.\left[\mathrm{F}^{-}\right]=0 \rightarrow 8.5 \times 10^{-3}\right)$. B) The corresponding changes in the emission spectrum upon excitation at $432 \mathrm{~nm}$

quenching, respectively. Furthermore, no noticeable shifts were observed in the $\lambda_{\max }$ upon addition of these anions. In contrast, ions such as $\mathrm{Br}^{-}$and $\mathrm{I}^{-}$did not give rise to any changes in the absorption spectrum of Ru-Nap- $\mathbf{N H}_{2}$, and the fluorescence emission was only marginally quenched (less than 5\%); excluding anion recognition by heavy atom effect quenching. ${ }^{26}$ We also carried out these spectroscopic titrations in DMSO and on all occasions, the same behaviour was observed as seen in $\mathrm{CH}_{3} \mathrm{CN}$ above. 
Having established that these anions gave rise to significant modulation in the MLCT based emission spectrum of RuNap- $\mathbf{N H}_{2}$, we carried out detailed anion titrations, observing the changes in both the ground and the excited state properties of $\mathbf{R u}-\mathbf{N a p}-\mathbf{N H}_{\mathbf{2}}$. The changes observed in the absorption spectrum upon titration with $\mathrm{F}^{-}$in $\mathrm{CH}_{3} \mathrm{CN}$ are shown in Figure 2A, and clearly demonstrate that the MLCT band was red-shifted upon interaction with $\mathrm{F}^{-}$, and that the high energy transitions were also affected. The changes in the absorption spectra were also found to be reversible upon addition of competitive hydrogen bonding solvents such as EtOH and water. We were able to analyse these results by fitting the absorption changes using the non-linear regression analysis programme SPECFIT, to both 1:1 and 1:2 (Host:Guest) binding stoichiometries. For $\mathrm{F}^{-}$, this gave $\log \mathrm{K}_{1: 1}=4.24( \pm 0.01)$ and $\log \mathrm{K}_{1: 2}=2.6$ $( \pm 0.13)$. Similarly, $\mathrm{F}^{-}$greatly affected the emission spectrum, which was quenched, as demonstrated in Figure 2B. Again, the changes were best fitted to two-step binding interactions, which gave $\log K_{1: 1}=4.20( \pm 0.25)$ and $\log$ $K_{1: 2}=3.7( \pm 0.37)$. While the former correlates well with the value determined from the changes in the absorption spectrum, the 1:2 binding interaction is significantly higher. The changes in the emission spectrum were reversible upon addition of water, where the emission was 'switched back on'. At higher concentrations of the sensor $\left(1.1 \times 10^{-3} \mathrm{M}\right)$ the recognition of $\mathrm{F}^{-}$was also clearly visible to the naked eye as demonstrated in the graphical abstract, whereby the solution changed from yellow to red. These changes were also reversible upon addition of water.

Similarly, the titration of $\mathbf{R u}-\mathbf{N a p}-\mathbf{N H}_{2}$ with $\mathrm{AcO}^{-}$and $\mathrm{Cl}^{-}$ also gave rise to changes in its absorption spectrum. However, these were, as demonstrated in Figure 1, much less pronounced than that seen for $\mathrm{F}^{-}$(Figure 2A), and we were unable to accurately determine the binding affinity

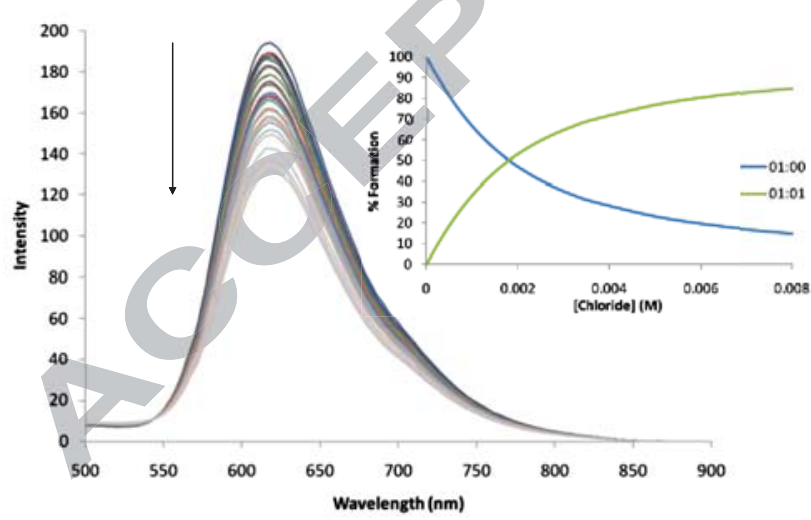

Figure 3. The changes observed in the emission spectrum of Ru-Nap- $\mathbf{N H}_{2}$ in $\mathrm{CH}_{3} \mathrm{CN}$ upon titration with TBACl: $\left[\mathrm{Cl}^{-}\right]=0 \rightarrow 8.5 \times 10^{-3} \mathrm{M}$. Inset: The speciation distribution diagram derived from the fitting of the changes in the emission spectrum.

from fitting these changes using non-linear regression analysis. Nevertheless, the concomitant changes in the emission spectrum were significant enough to allow for such analysis. The overall changes observed in the emission spectrum of Ru-Nap- $\mathbf{N H}_{2}$ upon titration with $\mathrm{Cl}^{-}$ are shown in Figure 3. Also shown in Figure 3, as an inset, is the speciation distribution diagram obtained after fitting the changes in the emission spectrum, which were best fitted to 1:1 stoichiometry; giving $\log K_{1: 1}=2.90( \pm 0.056)$. Similarly, $\mathrm{AcO}^{-}$gave rise to significant changes in the emission spectrum of $\mathbf{R u}-\mathbf{N a p}-\mathbf{N H}_{\mathbf{2}}$, which were best fitted to both $1: 1$ and $1: 2$ binding interactions, giving $\log \mathrm{K}_{1: 1}=$ $4.25( \pm 0.065)$ and $\log K_{1: 2}=3.11( \pm 0.081)$. As stated above, and demonstrated in Figure $1 \mathrm{~B}$, no measureable shifts were observed in the $\lambda_{\max }$ of the MLCT emission for these titrations. We also carried out titrations using $\mathrm{H}_{2} \mathrm{PO}_{4}^{-}$ and $\mathrm{HSO}_{4}{ }^{-}$. While $\mathrm{HSO}_{4}{ }^{-}$did not give rise to any significant changes in either the absorption or the emission spectrum, $\mathrm{H}_{2} \mathrm{PO}_{4}^{-}$gave rise to ca. $50 \%$ quenching in the MLCT emission. As well as both the MLCT and the $\pi-\pi$ transitions in the absorption spectrum being red-shifted (Figure 4A), the $\lambda_{\max }$ of the MLCT emission was significantly affected, being red-shifted by ca. $20 \mathrm{~nm}$ over the course of the titration. The changes in the absorption and the emission spectra are shown for the $\mathrm{H}_{2} \mathrm{PO}_{4}{ }^{-}$titration in Figures $4 \mathrm{~A}$ and $\mathrm{B}$, respectively, and demonstrate differing anion behaviour to that seen above in Figure 2. The changes in the emission spectrum in Figure 4B were best fitted using 1:1 binding stoichiometry, giving $\log \mathrm{K}_{1: 1}$

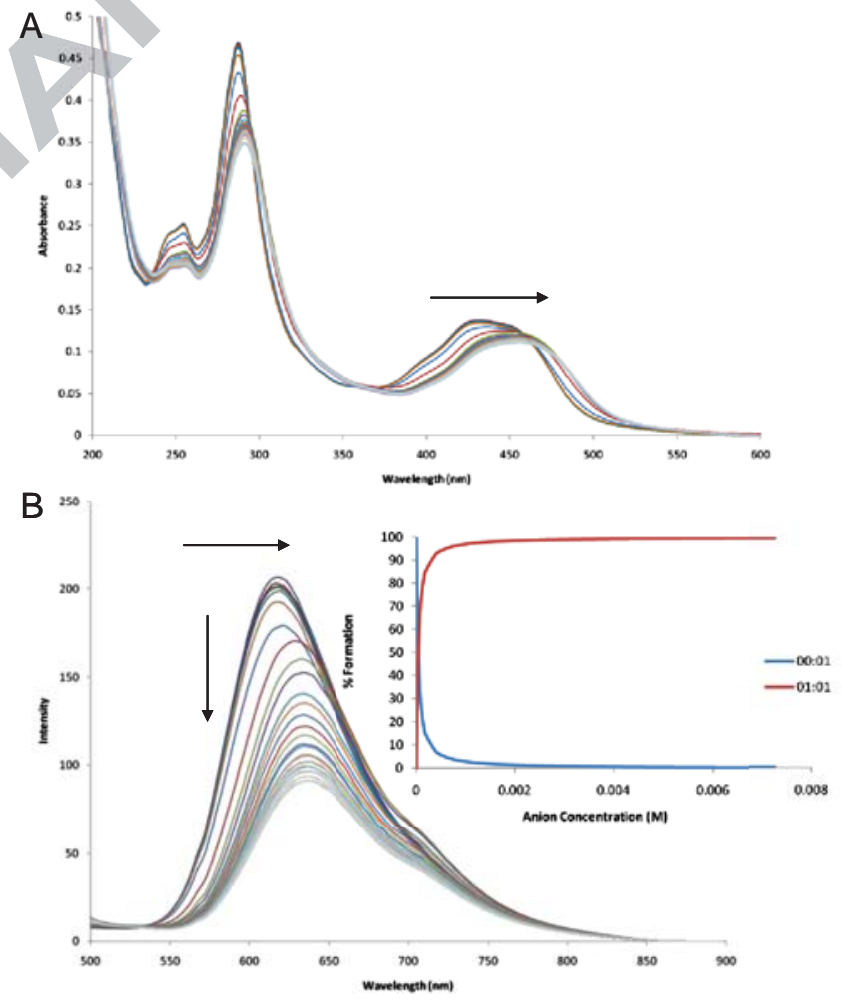

Figure 4. A) The changes in the absorption spectrum of $\mathbf{R u}-\mathbf{N a p}-\mathbf{N H}_{2}$ in $\mathrm{CH}_{3} \mathrm{CN}$ upon titration with $\mathrm{TBAH}_{2} \mathrm{PO}_{4}$ solution: $\left[\mathrm{H}_{2} \mathrm{PO}_{4}^{-}\right]=0 \rightarrow 6.7 \times 10^{-3}$ $\mathrm{M}$. B) The corresponding changes in the emission spectrum upon excitation at $432 \mathrm{~nm}$. Inset: The speciation distribution diagram derived from the fitting of the changes in the emission spectrum.

$=4.52( \pm 0.084)$, the speciation distribution diagram being shown in Figure 4B as an inset. To evaluate the specificity for $\mathrm{H}_{2} \mathrm{PO}_{4}^{-}$over other anions, the absorption and the emission spectra of $\mathbf{R u}-\mathbf{N a p}-\mathbf{N H}_{2}$ were recorded in the presence of excess $\mathrm{H}_{2} \mathrm{PO}_{4}^{-}$. Upon addition of excess $\mathrm{F}^{-}$, further quenching in the MLCT emission was observed. However, the emission was not blue-shifted back to the $\lambda_{\max }$ seen in Figure 2B. Despite this, the MLCT transition 
in the absorption spectrum (which mirrored that observed in Figure 4A prior to the addition of $\mathrm{F}^{-}$) was blue-shifted and the shoulder, centred at ca. $340 \mathrm{~nm}$ in Figure 2, disappeared. While it is difficult to draw any firm conclusions from this experiment, it does show that possibly more than one anion recognition mechanism is contributing to the changes seen above.

With a view to shedding some light on the sensing mechanism for the above anions, we also investigated the spectral changes in the ${ }^{1} \mathrm{H}$ NMR $(400 \mathrm{MHz})$, in both DMSO- $d_{6}$ and $\mathrm{CD}_{3} \mathrm{CN}$, of Ru-Nap- $\mathbf{N H}_{2}$ with $\mathrm{AcO}^{-}, \mathrm{Cl}^{-}$ and $\mathrm{F}^{-}$. In DMSO- $d_{6}$, all of these anions gave rise to significant changes in the ${ }^{1} \mathrm{H}$ NMR spectrum, where several resonances were shifted upfield upon addition of $\mathrm{AcO}^{-}$and $\mathrm{Cl}^{-}$. This would indicate that these anions are interacting with the sensors via possible hydrogen bonding between the anion and the 4-amino moiety of the naphthalimide fluorophore. Similarly, $\mathrm{F}^{-}$was also shown to give rise to large changes in the ${ }^{1} \mathrm{H}$ NMR, possibly due to deprotonation of the amine. Furthermore, in the case of $\mathrm{F}^{-}$, the formation of a triplet at ca. 16 ppm was also observed at higher equivalents, which is usually taken as an indication for the formation of $\mathrm{HF}_{2}{ }^{-18}$

When these ${ }^{1} \mathrm{H}$ NMR experiments were repeated in $\mathrm{CD}_{3} \mathrm{CN}$, the addition of these anions gave rise to precipitation, which is most likely due to anion exchange with the $\mathrm{PF}_{6}{ }^{-}$counterions, rendering $\mathbf{R u}-\mathbf{N a p}-\mathbf{N H}_{\mathbf{2}}$ insoluble at such a high concentration (mM vs, $\mu \mathrm{M}$ for absorption/fluorescence titrations).

On all accounts, this causes significant quenching of the MLCT based emission. Hence, it is possible that the formation of the MLCT excited state, achieved by population of the naphthalimide moiety (functioning as an antenna), as well as direct excitation of the MLCT band, is significantly diminished after this 'binding' event. However, $\mathrm{Cl}^{-}$would not normally be expected to be able to deprotonate the 4 -amino-napthalimide moiety, ${ }^{18}$ but the presence of the $\mathrm{Ru}(\mathrm{II})$ centre could contribute to an enhanced acidity of these protons. ${ }^{27} \mathrm{We}$ are currently analysing this in greater detail as well as investigating the use of other Ru(II) polypyridyl based complexes for use in luminescence anion sensing.

In summary, we have shown that the naphthalimide-based $\mathrm{Ru}(\mathrm{II})$-polypyridyl complex $\mathbf{R u}-\mathbf{N a p}-\mathbf{N H}_{\mathbf{2}}$ can function as a highly effective and long wavelength emissive fluorescent anion sensor for several anions in organic solution, where $\mathrm{F}^{-}$gives rise to the largest changes in both the absorption (which were visible to the naked eye) and the emission spectra, the latter being almost fully quenched.

\section{Acknowledgements}

We would like to thank TCD and IRCSET (Postgraduate Award to RBPE) for financial support and Dr. Emma B. Veale (TCD) and Dr. Susan J. Quinn (University College Dublin) for helpful discussions.

\section{Notes and References}

1. Gunnlaugsson, T.; Glynn, M.; Tocci (née Hussey), G. M.; Kruger, P. E.; Pfeffer, F. M. Coord. Chem. Rev. 2006, 250, 3094.

2. Sessler, J. L.; Gale, P. A.; Cho, W. S., Anion Receptor Chemistry; Royal Society of Chemistry: Cambridge, UK, 2006; Gunnlaugsson, T.; Ali H.D.P.; Glynn, M.; Kruger, P.E.; Hussey G. M. Pfeffer F. M.; dos Santos, C. M. G.; Tierney, J.; J. Fluoresc. 2005, 15, 287

3. Caltagirone, C.; Gale, P. A. Chem. Soc. Rev. 2009, 38, 520; Gale, P. A. Acc. Chem. Res. 2006, 39, 465; Gale, P. A. Quesada, R. Coord. Chem. Rev. 2006, 250, 3219; Steed, J. W. Chem. Commun. 2006, 2637; Beer, P. D.; Sambrook, M. R.; Curiel, D. Chem. Commun. 2006, 2105; Evans, L. S.; Gale, P. A.; Light, M. E.; Quesada, R. New. J. Chem. 2006, 30, 1019; Wu, F. Y.; Li, Z.; Guo, L.; Wang, X.; Lin, M. H.; Zhao, Y. F.; Jiang, Y. B. Org. Biomol. Chem. 2006, 4, 624; Ghosh, K.; Adhikari, S. Tetrahedron Lett. 2006, 47, 8165; dos Santos, C. M. G.; McCabe, T.; Watson, G. W.; Kruger, P. E.; Gunnlaugsson, T. J. Org. Chem. 2008, 73, 9235; Ali, H. D. P.; Quinn, S. J.; McCabe, T.; Kruger, P. E.; Gunnlaugsson, T. New J. Chem. 2009, 33, 793; dos Santos, C. M. G.; McCabe, T.; Gunnlaugsson, T. Tetrahedron Lett. 2007, 48, 3135; Lin, C.-I.; Selvi, S.; Fang, J.-M.; Chou, P.-T.; Lai, C.-H.; Cheng, Y.-M. J. Org. Chem. 2007, 72, 3537; Ghosh K.; Sen T.; Fröhlich R., Tetrahedron Lett. 2007, 48, 2935.

4 Pfeffer, F. M.; Gunnlaugsson, T.; Jensen, P.; Kruger, P.E. Org. Lett. 2005, 7, 5375; Evans, L. S.; Gale, P. A.; Light, M. E.; Quesada, R. Chem. Commun. 2006, 965; Jun, E. J.; Swamy, K. M. K.; Bang, H.; Kim, S. J., Yoon, J. Y. Tetrahedron Lett. 2006, 47, 3103.

5 Lee, J. W.; Park, S. Y.; Cho, B.-K.; Kim, J. S. Tetrahedron Lett. 2007, 48, 2541; Nicolini, J.; Testoni, F. M.; Schuhmacher, S. M.; Machado, V. G. Tetrahedron Lett. 2007, 48, 3467; Xu, Z.; Kim, S.; Lee, K.-H.; Yoon, J. Tetrahedron Lett. 2007, 48, 3797; Luxami, V.; Kumar, S. Tetrahedron Lett. 2007, 48, 3083; Devaraj, S.; Saravanakumar, D.; Kandaswamy, M. Tetrahedron Lett. 2007, 48, 3077.

6 dos Santos, C. M. G.; Gunnlaugsson T. Tetrahedron Lett. 2007, 48, 3135; dos Santos, C. M. G.; Gunnlaugsson T. Dalton Trans. 2009, 4712.

7 Duke, R. M.; O’Brien, J. E.; McCabe T.; Gunnlaugsson, T. Org. Biomol. Chem. 2008, 6, 4089; Quinlan, E.; Matthews, S. E.; Gunnlaugsson T. Tetrahedron Lett. 2006, 47, 9333; Pfeffer F. M.; Buschgens, A. M.; Barnett, N. W.; Gunnlaugsson, T.; Kruger, P. E., Tetrahedron Lett. 2005, 46, 6579; Gunnlaugsson T.; Davis, A. P.; Glynn, M. Chem. Commun. 2001, 2556.

8 Lowe, A. J.; Dyson, G. A.; Pfeffer, F. M. Org. Biomol. Chem. 2007, 5, 1343; Pfeffer, F. M.; Lim K. F.; Sedgwick, K. J. Org. Biomol. Chem. 2007, 5, 1795; Pfeffer, F. M.; Kruger, P. E.; Gunnlaugsson T. J. Org. Biomol. Chem. 2007, 5, 1894; Pfeffer, F. M.; Seter, M.; Lewcenko, N.; Barnett, N. W. Tetrahedron Lett. 2006, 47, 5251.

9 García-España, E.; Díaz, P.; Llinares, J. M.; Bianchi A. Coord. Chem. Rev. 2006, 250, 2952.

10 Schmuck, C. Coord. Chem. Rev. 2006, 250, 3053.

11 Fan, S-H.; Li, Q.; Wang K-Z. Inorg. Chem. Acta. 2009, 362, 5155; dos Santos C. M. G Gunnlaugsson, T. Supramol. Chem. 2009, 21, 173; Goswami. S.; Chakrabarty. R. Tetrahedron Lett. 2009, 44, 5994; Zapata, F.; Caballero, A.; Espinosa, A.; Tárraga, A.; Molina, P. Org. Chem. 2008, 73, 4034; Fisher, M. G.; Gale, P. A.; Light, M. E.; Loeb, S. J. Chem. Commun. 2008, 5695; Perez. J.; Riera, L. Chem. Soc. Rev. 2008, 37, 2658; Ghosh. A.; Ganguly. B.; Das. A. Inorg. Chem. 2007, 46, 9912; Pelleteret, D.; Fletcher, N. C.; Doherty, A. P. Inorg. Chem. 2007, 46, 4386; Ros-Lis, J. V.; Martinez-Manez, R.; Soto, J.; McDonagh, C.; Guckian, A. Eur. J. Inorg. Chem. 2006, 2647.

12 Yang, R.; Liu, W.-X.; Shen, H.; Huang, H.-H.; Jiang, Y.-B. J. Phys. Chem. B. 2008, 112, 5105; Ali, H. D. P.; Kruger, P. E. Gunnlaugsson, T. New. J. Chem. 2008, 32, 1153.

13 Gunnlaugsson, T.; Kruger, P. E.; Jensen, P.; Tierney, J.; Ali H.D.P.; Hussey G. M. J. Org. Chem. 2005, 70, 10875.

14 Examples include: Lin, C.; Simov, V.; Drueckhammer, D. G. J. Org. Chem, 2007, 72, 1742; Davis A. P.; O'Brien J. E.; Glynn M. Org. Biomol. Chem. 2005, 3, 48; Gunnlaugsson T.; Davis A. P.; Hussey, G. M.; Tierney J.; Glynn M. Org. Biomol. Chem. 2004, 2, 1856; Gunnlaugsson T.; Davis, A. P.; O’Brien, J. E.; Glynn, M. Org. Lett. 2002, 4, 2449

15 Camiolo, S.; Gale, P.; Hursthouse, M. B.; Light, M. E. Org. Biomol. Chem. 2003, 1, 741. 
16 Li, Y.; Cao, L. F.; Tian, H. J. Org. Chem, 2006, 71, 8279; Xu, Z -W.; Tang, J.; Tian, H. Chin. Chem. Lett. 2008, 19, 1353; Liu, B.; Tian, H. J. Mater. Chem. 2005, 15, 2681; Liu, B.; Tian, H. Chem. Lett. 2005, 34, 686.

17 Amendola V, Esteban-Gomez D, Fabbrizzi L, Liechelli, M. Acc. Chem. Res. 2006, 44, 8690; Esteban-Gomez, D.; Fabbrizzi, L.; Liechelli, M. J. Org. Chem. 2005, 70, 5717; Bonizzoni. M.; Fabbrizzi, L.; Taglietti, A.; Tiengo, E. Eur. J. Org. Chem. 2006, 3567.

18 Veale, E. B.; Tocci, G. M.; Pfeffer, F. M.; Kruger, P. E. Gunnlaugsson, T. Org. Biomol. Chem. 2009, 7, 3447; Veale, E. B.; Gunnlaugsson, T. J. Org. Chem. 2008, 73, 8073; Duke, R. M.; Gunnlaugsson, T. Tetrahedron Lett. 2007, 48, 8043; Gunnlaugsson, T.; Kruger, P. E.; Lee, T. C.; Parkesh, R.; Pfeffer, F. M.; Hussey, G. M. Tetrahedron Lett. 2003, 44, 6575; Gunnlaugsson, T., Kruger, P. E., Jensen, P., Pfeffer, F. M.; Hussey, G. M. Tetrahedron Lett. 2003, 44, 8909.

19 Parkesh, R.; Lee, T. C.; Gunnlaugsson, T. Tetrahedron Lett. 2009, 50 , 4114; Gunnlaugsson, T.; Lee, T. C.; Parkesh, R. Org. Biomol. Chem. 2007, 5, 310; Gunnlaugsson, T.; Lee, T. C.; Parkesh, R. Org. Biomol. Chem. 2003, 1, 3265.

20 (a) Veale, E. B.; Frimannsson, D. O.; Lawler, M. Gunnlaugsson, T. Org. Lett. 2009, 11, 4040; (b) Ryan, G. J.; Quinn, S.; Gunnlaugsson, T. Inorg. Chem. 2008, 47, 401.

21 Cametti, M.; Rissanen. K. Chem. Commun. 2009, 2809.

22 Bayly, S. R.; Beer, P. D. Struct. Bond. 2008, 129, 45; Pratt, M. D.; Beer, P. D.; Tetrahedron. 2004, 49, 11227.

23 Plitt, P.; Gross, D. E.; Lynch, V. M.; Sessler, J. L. Chem. Eur. J. 2007, 13, 1374; Mizuno, T.; Wei, W. H.; Eller, L. R.; Sessler, J. L. J. Am. Chem. Soc. 2002, 124, 1134

24 Saha, D.; Das, S.; Bhaumik, C.; Dutta, S.; Baitalik, S. Inorg. Chem. 2010, 49, 2334.

25 Berni, E.; Gosse, I.; Badocco, D.; Pastore, P.; Sojic, N.; Pinet, S. Chem. Eur. J. 2009, 15, 5145.

26 Gunnlaugsson, T.; Bichell, B.; Nolan, C. Tetrahedron, 2004, 60, 5799.

27 The effect seen in Figure 3 could also be be due to contribution from counter ion exchange, a phenomenon that has not been extensively explored for use in such anion sensing. 


\section{Schemes and figures}

\section{Scheme 1}<smiles>O=C1c2cccc3c([N+](=O)[O-])ccc(c23)C(=O)N1c1ccc(-c2ccnc(-c3ccccn3)c2)cc1</smiles>

Nap- $\mathrm{NO}_{2}$ (i)

(ii)<smiles></smiles>

Ru-Nap- $\mathrm{NH}_{2}$

Scheme 1. Synthesis of the Ru(II) based sensor Ru-Nap- $\mathbf{N H}_{2}$ from the precursor Nap$\mathbf{N H}_{2}$. (i) $\mathrm{Ru}$ (bpy) ${ }_{2} \mathrm{Cl}_{2}, \mathrm{DMF} / \mathrm{H}_{2} \mathrm{O}, \mathrm{Ar}, \Delta$; (ii) $\mathrm{Pd} / \mathrm{C}, \mathrm{MeOH}$. 